\section{Arterial oxygen desaturation during peripheral venous cannulation in children}

K.K. Gombar MD, S.S. Nain DA MD, B. Singh MD, S. Satinder MD, B. Chhabra DA MS

\begin{abstract}
Arterial oxygen saturation $\left(\mathrm{SpO}_{2}\right)$ was measured to determine oxygen desaturation during peripheral venous cannulation prior to induction of anaesthesia in 40 consecutive patients in each of the three age groups; Group I: 1-4 mo, Group II: 4-12 mo, Group III: 12-24 mo. Following premedication with oral trimeprazine tartarate $3 \mathrm{mg} \cdot \mathrm{kg}^{-1}$, one to two hours before operation, baseline $\mathrm{SpO}_{2}$ was noted with child breathing room air. Continuous monitoring during peripheral venous cannulation was done and maximum decrease and duration of $\mathrm{SpO} \mathrm{O}_{2}$ $<90 \%$ was noted. Decreases in mean $\mathrm{SpO}_{2}, 3.2 \pm 1.4$ in Group I. $2.6 \pm 2.0$ in Group II and $1.7 \pm 1.9$ in Group III, were observed $(P<0.001)$. Desaturation $\geq 4 \%$ was noted in 17 patients in Group I, ten patients in Group II and six patients in Group III. Two children, one each in Groups I and II, experienced $\mathrm{SpO}_{2}<90 \%$ for $30 \mathrm{sec}$ and $80 \mathrm{sec}$ respectively. We conchude that clinically undiagnosed desaturation occurs during peripheral venous cannulation in healthy children. The authors suggest that continuous monitoring of $\mathrm{SpO}_{2}$ using pulse oximetry should be performed routinely during peripheral venous cannulation
\end{abstract}

Pour évaluer la désaturation en axygène, la saturation artérielle $\left(\mathrm{SpO}_{2}\right)$ est mesurée avant linduction de lanesthésie chez 40 patients consécutifs représentant un des trois groupes d'âges suivant; groupe I: 1-4 mois, groupe II: 4-12 mois, groupe III: 12-24 mois. Après une prémédication au tartrate de triméprazine oral $3 \mathrm{mg} \cdot \mathrm{kg}^{-1}$ administrée une $\dot{a}$ deux heures avant lintervemion, on établit une ligne de base pendant que l'enfant respire de l'air. Un monitorage continu est installe avant la camulation d'une veine périphérique; on note la plus grande diminution de la $\mathrm{SpO}_{2}$ et la durée de la $\mathrm{SpO}_{2}<90 \%$. On

Key words

ANAESTHESIA: paediatric;

HYPOXIA:

MEASUREMENT TECHNIQUES: pulse oximetry.

From the Department of Anaesthesiology, Medical College and Hospital, Rohtak 124001, India.

Address correspondence to: Dr. Kanti K. Gombar, 35/9 J,

Medical Enclave, Rohtak-124001, Haryana, India.

Accepted for publication 21st December, 1993. observe des baisses de la $\mathrm{SpO}_{2}$ moyenne de 3,2 $\pm 1,4$ pour le groupe I; de 2,6 $\pm 2,0$ pour le groupe II et de $1,7 \pm 1,9$ pour le groupe III $(P<0,001)$. Une désaturation $\geq 4 \%$ est notée chez 17 patients dans le groupe I, dix patients dans le groupe II et chez siz patients dans le groupe III. Deux enfants, um du groupe I et l'autre du groupe II ont présenté une $\mathrm{Sp} \mathrm{O}_{2}$ $<90 \%$ pour 30 secondes et 80 secondes respectivement. Nous concluons que des désaturations non décelables cliniquement surviennent prendant la canulation veineuse chez des enfants bien portants et suggérons un monitorage systématique continu de la $\mathrm{Sp} \mathrm{O}_{2}$, par oxymétrie pulsée pendant la canulation diune veine périphérique chez l'enfant.

Intravenous induction of anaesthesia in children is associated with a greater degree of hypoxaemia than is inhalational induction. ${ }^{1}$ Peripheral venous cannulation is a painful procedure which makes the child more anxious, uncomfortable and uncooperative and this may effect arterial oxygen desaturation during induction of anaesthesia. 1,2

Arterial oxygen desaturation has been documented in adult cardiac patients during placement of invasive monitoring lines, ${ }^{3}$ but oxygen desaturation during venous cannulation in healthy children has not been reported. Induction of anaesthesia reduces oxygen reserves, ${ }^{4}$ and in combination with oxygen desaturation, which may occur during peripheral venous cannulation, can lead to increased morbidity and mortality.

The present study was conducted to measure arterial oxygen saturation $\left(\mathrm{SpO}_{2}\right)$ using non-invasive pulse oximetry to determine the need for monitoring $\mathrm{SpO}_{2}$ during establishment of intravenous lines in premedicated, unanaesthetized otherwise healthy children scheduled for routine elective surgery.

\section{Methods}

The study was conducted in 40 consecutive ASA I and II children in each of three groups scheduled for elective surgery under general anaesthesia; Group I: 1-4 mo, Group II: 4-12 mo, Group III: 12-24 mo. The children were selected irrespective of sex and weight. Children 
with cardiorespiratory disease, haematological abnornality and unstable haemodynamic status were not included in the study. The patients in whom preinduction values of blood pressure, heart rate, $\mathrm{SpO}_{2}$ were not accurately obtained due to improperly applied probes, patient movement or plethysmographic waveform failure on pulse oximetry were excluded from the study.

The protocol was approved by the Hospital Ethics Committee and informed consent from the parents was taken. After three to five hours of fasting, oral trimeprazine tartarate $3 \mathrm{mg} \cdot \mathrm{kg}^{-1}$ was given as premedication one to two hours before operation. A finger or flexible probe of the pulse oximeter (Ohmeda Biox 3700, USA) was attached and a baseline $\mathrm{SpO}_{2}$ reading was noted with the child positioned under a servo-controlled overhead radiant warmer (Ameda, Switzerland) and breathing room air. Continuous monitoring of $\mathrm{SpO}_{2}$ during cannulation was done and the maximum decrease and the duration of $\mathrm{SpO}_{2}<90 \%$ was noted. Cannulation was performed using $22 \mathrm{G}$ Teflon cannula (Vygon, France) on the dorsum of hand or foot by an experienced anaesthetist and patients in whom cannulation required more than two attempts were excluded from the study.

The results were analysed using Student's paired and unpaired $t$ tests for continuous variables. A $P$ value of $<0.05$ was considered statistically significant.

\section{Results}

The mean age, weight and haemoglobin concentration in the three groups is shown in Table I.

Establishment of the intravenous line led to a decrease in the mean $\mathrm{SpO}_{2}$ from baseline by $3.2 \%$ in Group I, $2.6 \%$ in Group II and $1.7 \%$ in Group III $(P<0.001)$. The decrease in mean $\mathrm{SpO}_{2}$ was found to be greater in Group I than in Group II $(P<0.01)$, in Group I than in Group III $(P<0.001)$ and in Group II than in Group III $(P<0.01)$.

The incidence of arterial oxygen desaturation of $\geq 4 \%$ from baseline was observed in 17 patients in Group I, ten in Group II and in six in Group III. In two patients $\mathrm{SpO}_{2}$ was $<90 \%$. In one, Group I, the duration of desaturation was $30 \mathrm{sec}$ and in the other, Group II, was 80 sec (Table II).

\section{Discussion}

The induction of general anaesthesia in children may be more difficult than in adults due to anatomical and physiological differences, no matter what technique is selected. Children under one year of age are more susceptible to a rapid decrease in arterial oxygen saturation due to lower functional residual capacity ${ }^{5}$ and higher metabolic rate which result in increased oxygen requirements. ${ }^{6}$ Any decrease in the critical level of $\mathrm{SpO}_{2}(90 \%)$ from birth to
TABLE I Patient data

\begin{tabular}{lccl}
\hline $\begin{array}{l}\text { Group } \\
(n=40)\end{array}$ & $\begin{array}{l}\text { Age }(\mathrm{mo}) \\
\text { Mean } \pm S D\end{array}$ & $\begin{array}{l}\text { Weight }(\mathrm{kg}) \\
\text { Mean } \pm S D\end{array}$ & $\begin{array}{l}\text { Haemoglobin } \\
\left.(\mathrm{g} \cdot \mathrm{dr})^{-1}\right) \\
\text { Mean } \pm S D\end{array}$ \\
\hline I & $2.6 \pm 1.1$ & $4.5 \pm 1.0$ & $10.9 \pm 1.4$ \\
II & $9.8 \pm 2.4$ & $7.9 \pm 1.3$ & $10.2 \pm 0.8$ \\
III & $22.3 \pm 2.9$ & $10.6 \pm 1.3$ & $10.1 \pm 0.7$ \\
\hline
\end{tabular}

TABLE II Effect of intravenous cannulation on oxygen saturation

\begin{tabular}{llll}
\hline & Group I & Group II & Group III \\
\hline Baseline $\mathrm{SpO}_{2}$ & & & \\
- Mean $\pm \mathrm{SD}$ & $95.8 \pm 0.8$ & $96.6 \pm 1.2$ & $97.2 \pm 1.4$ \\
- Range & $95-98$ & $95-100$ & $95-99$ \\
Minimum $\mathrm{SpO}_{2}$ during & & & \\
$\quad$ cannulation & & & \\
- Mean $\pm \mathrm{SD}$ & $92.6 \pm 1.3^{*}$ & $94.0 \pm 2.5^{*}$ & $95.5 \pm 2.4^{*}$ \\
- Range & $89-95$ & $85-100$ & $90-99$ \\
Mean decrease in $\mathrm{SpO}_{2}$ & & & \\
- Mean $\pm \mathrm{SD}$ & $3.2 \pm 1.4$ & $2.6 \pm 2.0$ & $1.7 \pm 1.9$ \\
$\begin{array}{l}\text { Desaturation } \geq 4 \%(n) \\
\text { SpO }\end{array}$ & 17 & 10 & 6 \\
Duration of $\mathrm{SpO}_{2}<90 \%$ & 1 & 1 & - \\
$\quad$ (sec) & 30 & 80 & - \\
\hline
\end{tabular}

$\because P<0.001$

the age of four months is associated with a greater decrease in arterial oxygen tension due to the presence of fetal haemoglobin which has a higher affinity for oxygen than does adult haemoglobin. ' In addition, the child may be uncooperative and refuse to breathe oxygen prior to induction of anaesthesia.

The incidence and degree of desaturation of arterial oxygen during peripheral venous cannulation particularly in children less than one year of age, in the present study, was statistically significant. Although not clinically evident, $\mathrm{SpO}_{2}$ of less than $90 \%$ was observed in two children under the age of one year. The brief periods of hypoxaemia, particularly in the otherwise fit children, may be well tolerated, but the oxygen reserves are considerably reduced. Changes in alveolar gas tension occur even in a smooth transition from awake to anaesthetized states, ${ }^{8}$ but factors like airway obstruction, difficulty in tracheal intubation and an already low $\mathrm{P}_{50}$ in children may further aggravate hypoxaemia and thus affect cellular oxygenation. ${ }^{9}$

Hensely $e t a l{ }^{3}$ in a study of 20 cardiac patients breathing room air showed hypoxaemia $\left(\mathrm{SpO}_{2}<90 \%\right.$; lowest $\mathrm{SpO}_{2} 74 \%$ ) in 12 patients during placement of invasive monitoring lines prior to induction of anaesthesia. This phenomenon, however, has not been reported in paediatric surgical patients. 
Arterial oxygen desaturation while establishing an iv line may be explained by the relationship between the activity of the child and oxygen consumption, together with hyperventilation leading to low carbon dioxide tension and reduced respiratory drive. ${ }^{10}$ An anxious child who is mildly hypocapnoeic remains apnoeic for longer until sufficient $\mathrm{CO}_{2}$ is retained to provide a stimulus to breathing. " These lower values of $\mathrm{SpO}_{2}$ in crying and restless children may also be exacerbated by increased secretions and an abnormal pattern of breathing. ${ }^{2}$ Another possibility is that the anaesthetist who has finally achieved a successful venepuncture in a screaming child may be so relieved that a slight delay may occur before airway control is secured.

In conclusion, reduced $\mathrm{SpO}_{2}$ values in the present study were common during peripheral venous cannulation before induction of anaesthesia in children. There was no evidence that any child was harmed by hypoxaemia. However, the majority of the children in our study had been closer to $\mathrm{SpO}_{2} 90 \%$, a point from where saturation may drop steeply during induction of anaesthesia without the warning given by pulse oximeter. We therefore recommend monitoring oxygen saturation using pulse oximetry during placement of intravenous cannula, and preoxygenation in children should start from the time of peripheral venous cannulation prior to induction of anaesthesia.

\section{References}

1 Laycock GJA, McNicol LR. Hypoxaemia during induction of anaesthesia - an audit of children who underwent general anaesthesia for routine elective surgery. Anaesthesia 1988; 43: 981-4.

2 Walther-Larsen $S$, Sloth $M$, Valentin $N$. Arterial desaturation in healthy children during and after minor surgery. Acta Anaesthesiol Scand 1991; 35: 621-5.

3 Hensley FA Jr, Dodson DL, Martin DE, Stauffer RA, Larach $D R$. Oxygen saturation during placement of invasive monitoring in the premedicated, unanaesthetized cardiac patient. Anesthesiology 1986; 65: A22.

4 Knill $R L$. Evaluation of arterial oxygenation during anaesthesia. Can Anaesth Soc J 1985; 32: S16-9.

5 Motoyama EK, Brinkmeyer SD, Mutich RL, Waczak SA. Reduced FRC in anesthetized infants: effect of low PEEP. Anesthesiology 1982; 57: A418.

6 Cross KW, Tizard JPM, Trythall DAH. The gaseous metabolism of the newborm infant. Acta Paediatr 1957; 46: 265-85.

7 Oski FA. Designation of anemia on a functional basis. $\mathrm{J}$ Pediatrics 1973; 83: 353-4.

8 Marshall BE, Wyche $M Q J$ r. Hypoxaemia during and after anesthesia. Anesthesiology 1972; 37: 178-209.

9 Drummond $G B$, Park $G R$. Arterial oxygen saturation be- fore intubation of the trachea. An assessment of oxygenation techniques. Br J Anaesth 1984; 56: 987-92.

10 Evelyn $R$, Steward DJ. Oxygen consumption in infants in the early postoperative period: effect of analgesic therapy and subsequent activity. Can J Anaesth 1987; 34: S95-6.

11 Drummond $G B$. Rapid inhalation induction of anaesthesia (Editorial). Br J Anaesth 1988; 61: 373-5. 